\title{
Impact of sugar beet seed priming using the SMP method on the properties of the pericarp
}

\author{
C. Chomontowski ${ }^{*}$ (i) and S. Podlaski
}

\begin{abstract}
Background: This study determined the effects of two solid matrix priming methods on changes in the characteristics of two lots of the same variety of sugar beet fruits that differ in the level of vigour.

Results: Seed treatment within each level of vigour did not significantly affect helium and apparent density, total pore volume and total porosity. However, there was a tendency to increase porosity due to priming. This is probably why seed priming significantly increased mesopore diameter in both high and low vigour seeds. These changes increased the water content in the pericarp and the seeds and increased the water potential during germination. The high level of electrical conductivity of the fruit extracts was associated with low seed vigour. Low vigour resulted in higher humidity of the pericarp and decreased seed moisture and was also associated with lower water potential of the pericarp and seeds.

Conclusions: A significant difference in the water content in the pericarp and seeds was indicative of imbibition and problems with water flow between these centres, which resulted in a low water diffusion coefficient of the pericarp. This low water diffusion coefficient was correlated with the prolongation of the seed germination time.
\end{abstract}

Keywords: Porosity, Density, Water content, Water potential, Germination

\section{Background}

Water availability is one of the basic factors determining the seed germination process. Moreover, water availability is determined by the properties of the germination medium and by the morphological, anatomical and physicochemical properties of the fruits. The most important environmental factors include the gradient of water potential, the water transport parameters in the germination medium and the conductivity and diffusivity of the soil [12].

A sugar beet fruit is composed of a hard pericarp, whose mass varies from 70 to $80 \%[22,33]$ of the raw fruit. Inside the pericarp, there is a kidney-shaped botanical seed $[2,8,13,14,19]$. The beet pericarp can restrict the water and oxygen uptake of an enclosed seed $[8,13$, $18,25,27,30,31,34]$. The upper part of the pericarp is covered with an ovary cap (operculum), on which the remnants of the stigma are placed. Sometimes there is a hole that remains in the ovary cap after the transmission channel [27]. On the opposite side of the operculum, there is a place where the fruit attaches to the shoot, which is called the basal pore. The basal pore is probably the most important place for water to flow to the seed $[2,8,14,25]$. The structure of the pericarp, the size of the basal pore and its degree of tissue filling are genetically determined by the maternal genotype.

SEM analysis of fruits from 48 Polish sugar beet lines has shown, that a beet pericarp consists of three layers [28]. The first layer in the vicinity of the seed cavity is made of small sclereids with thick cell multi-layer walls. Large, single crystals of chemical compounds are present in this layer. The middle layer of the pericarp is made of sclereids with thinner cell walls. Inside these sclereids, there are clusters of numerous small crystals of chemical

* Correspondence: chrystian_chomontowski@sggw.pl

Department of Plant Physiology, Institute of Biology, Warsaw University of

Life Sciences SGGW, 159 Nowoursynowska St, 02-776 Warsaw, Poland

(C) The Author(s). 2020 Open Access This article is distributed under the terms of the Creative Commons Attribution 4.0 International License (http://creativecommons.org/licenses/by/4.0/), which permits unrestricted use, distribution, and

reproduction in any medium, provided you give appropriate credit to the original author(s) and the source, provide a link to the Creative Commons license, and indicate if changes were made. The Creative Commons Public Domain Dedication waiver (http://creativecommons.org/publicdomain/zero/1.0/) applies to the data made available in this article, unless otherwise stated. 
compounds. The second layer of the pericarp gradually passes into the third layer, which is made of parenchyma cells. However, in the fruit of some commercial varieties it is difficult to separate two layers of sclerenchyma tissue.

The pericarp thickness in the basal pore ranges from 0.6 to $0.96 \mathrm{~mm}$ [27]. The ratio of the pericarp parenchyma layer thickness to the sclerenchyma layer thickness determines the density, water potential and water flow through the pericarp. The pericarp density varies from 0.56 to $1.10 \mathrm{~g} \mathrm{~cm}^{-3}$ [27]. Because parenchyma is loose tissue and sclerenchyma is compact and dense, the thicker the sclerenchyma tissue is in relation to the thickness of whole pericarp (e.g., as a result of fruit polishing), the higher the density of the pericarp and the lower the general porosity and water potential of the pericarp are at a given time.

$\mathrm{X}$-ray analysis of the chemical compound crystals showed that they include the following elements: potassium, calcium, magnesium, phosphorus, chlorine and sulphur. Based on the analysis of fruit water extracts, potassium, sodium [15] magnesium and calcium are predominant among the cations, whereas nitrate, chloride, phosphate and sulphate oxalate [16] are predominant among the anions [18]. Crystals dissolve in water during seed imbibition, which results in the formation of a solution with a low osmotic potential and a high electric conductivity in the pericarp [26]. This solution inhibits the water flow through the pericarp, which is reflected in the low pericarp water diffusion coefficient [27].

Hadas [12] and Blunk et al. [3] point out that water flow through pericarp or seed coat is important for seed germination. One of the measures of water flow is the water diffusion coefficient. Podlaski [27] assessed the value of the pericarps water diffusion coefficient in raw fruits originating from 48 sugar beet breeding lines reproduced in Poland. The average water diffusion coefficient of the pericarp during the germination period was $0.00134 \mathrm{~cm}^{2} \mathrm{~d}^{-1}$ [27]. Seed coat water diffusion of chickpea, pea, and vetch ranged from 0,03 to 0 , $00009 \mathrm{~cm}^{2} \mathrm{~d}^{-1}$. The lower values were for low seed coat hydration [12].

In addition to the inorganic compounds of osmotic character in the pericarp, many organic compounds have been identified: vanillic acid, p-oxybenzoic acid, ferulic acid, coumarin acid, chlorogenic acid, ABA, rutin and protocatechuic acid [10, 13, 14, 30, 31] Interestingly, levels of several endogenous plant growth regulators, which were shown to influence the germination or early root growth, greatly differed between the pericarp and the true seed. Consequently, the pericarp is assumed to play an important role during the germination and seedling growth of sugar beet [1]. There is a lack of information regarding whether these germinationinhibiting compounds affect the flow of water through the pericarp.

There is also no obvious answer to the question of whether the water penetrates the pericarp through the whole surface or whether there are special flow points (pores), i.e., points of entry. Chachalis and Smith [6] showed that the presence of a high density of deep and open pores in a soybean seed coat was connected with the rapid permeability of the seed coat. According to Manz et al. [20], the micropylar tobacco seed end is the major entry point of water. The research of Juntilla [18] and Podlaski [27], who covered the base of the fruit, the top of the operculum and the surfaces around it with a silicone paste, showed that the main point of water entry might be the basal pore.

The low water potential of the pericarp causes a reduction in the flow of water to the seed, creating a kind of barrier. The water potential of seeds just before the emergence of the germinal root is approximately -1.0 $\mathrm{MPa}[4,27]$, therefore any environmental factor or seed property that delays the achievement of such a water potential level prolongs the germination process [29].

To improve the germination of sugar beet seeds, priming processes are commonly used. The physiological effects of priming (increased germination and emergence speed) are well known $[7,11,21,24]$. However, there is a lack of knowledge about whether and to what extent the effects of priming depend on changes in the properties of pericarp to increase the flow of water. This study attempts to answer this question.

\section{Methods}

Throughout the paper, the term "fruit" refers to the sugar beet dispersal unit, and "seed" refers to the botanically true seed and includes the embryo, perisperm, and endosperm and seed coat remnants.

Seeds of Sugar beet were collected from plants in Cesena town, Forlì-Cesena county, Romagna province, Italy

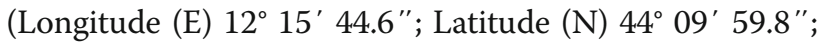
Altitude $25 \mathrm{~m}$ ). As Sugar beet spp. are not endangered, collection of samples for scientific purposes was permitted by local legislation. Professor Sławomir Podlaski, plant physiology major of Warsaw University of Life Sciences participated in the identification of specimens. The voucher specimen has not been deposited in any publicly available herbarium.

\section{Material}

The research was carried out in 2013-2015. The study subjects were sugar beet fruits from 2 lots of the Polish commercial variety Janosik that differ in the level of vigour. Janosik variety was registered in year 2010, it is a diploid variety in normal type. It is resistant to 
rhizomania, has no tendency to bolting, develop high root and technological sugar yield, has low content of molasses and good processing properties. The average germination rate of seeds at $10^{\circ} \mathrm{C}$ and $15{ }^{\circ} \mathrm{C}$ was assumed as a criterion of vigour in an optimum filter paper humidity of $60 \%$ full water capacity (FWC). Both fruit lots were characterized by a germination ability of 93 to $99 \%$ after 14 days (Table 1). Seeds were grown and produced in Po Valley (Italy). Harvested and dried seeds were subjected to pre-cleaning. Then seeds were transported to Poland and subjected to further stages of seed treatments. Each year the seeds were stored in cotton bags at room temperature and humidity. Fruit humidity varied in range of $8-9 \%$. The characteristics of control fruits polished and rinsed in water collected in the years 2013-15 are presented in Table 1.

The best seeds with high vigour were obtained in 2013. They were characterized by high germination ability after 4 days, fast germination, lowest electric conductivity of fruit water extracts, relatively high total porosity and the largest mesopore diameter.

Before starting the tests, the fruits (including control combination) were polished and rinsed in water at $20^{\circ} \mathrm{C}$ for $2 \mathrm{~h}$, in accordance with the Kutnowska Hodowla Buraka Cukrowego Sp. z o. o. (KHBC) technology. $\mathrm{KHBC}$ is state-owned (polish) sugar beet breeding company.

Two seed priming technologies were used: Quick Beet (QB) (Podlaski S., Wzorek H., Chrobak Z., Polish patent, PL 207240, June 29th, 2005) and Quick Beet-1 (QB-1) (Podlaski S., Wzorek H., Chrobak Z., Polish patent, PL 216893, April 1st, 2011). Both methods used in this study are based on solid matrix priming (SMP) and use of zeolites as water carriers. The seeds are mixed with sodium zeolite NK 10 CECA in a specific ratio for a certain among of time, then separated on special sieves and allowed to dry.

\section{Physical properties of the pericarp}

The physical properties of the pericarp were assessed after removing the operculum and seeds in the
Department of Ceramics and Refractories at the AGH University of Science and Technology. The following physical parameters were determined: the helium density (helium pycnometer ACCuPyc 1330) which determines the density of the material with no pores determined on the basis of the material volume measurement; the apparent density, which is the ratio of the weight of the pericarp to its volume with pores; the total porosity, (GeoPyc 1360, density analyzer) which is the ratio of the volume of all pores to the total volume and the mezospore diameters (ASAP 2010 System) [23]. All instruments were obtained from Micrometrics Company, USA.

Helium density measurements were carried out using 10 helium flushes and 5 replicates of volume determination. The samples were dried at $105{ }^{\circ} \mathrm{C}$ before measurements and their mass was approximately $1.4 \mathrm{~g}$. For apparent density, total porosity and total pore volume measurements the $0.36 \mathrm{~g}$ samples of pericarp were dried at $105^{\circ} \mathrm{C}$ before measurements.

Before adsorptive measurement, the $1 \mathrm{~g}$ samples of pericarp were degassed at $105^{\circ} \mathrm{C}$ Adsorption measurements were made at liquid nitrogen temperature using nitrogen as the adsorbate. Based on the measurements, specific surface area of materials $\left(\mathrm{S}_{\mathrm{BET}}\right)$ and mesopores volume were evaluated.

\section{Water potential and water content of the pericarp and seeds}

The water potential of the seeds and pericarp was determined using a Dew Point Microvoltmeter HR-33 T and a C-52 measuring chamber (Wescor Inc., USA) after 2, 8,24 and $48 \mathrm{~h}$ after placing the seeds on moist filter paper at a temperature of $15{ }^{\circ} \mathrm{C}$ and a filter paper humidity of $60 \%$ FWC. The tests were carried out in 5 replicates, and the incubation period of the seeds and pericarp in the measuring chamber was $15 \mathrm{~min}$. The seeds were manually removed from the pericarp.

The water content of the seeds and pericarp was also determined after 2, 8, 24 and $48 \mathrm{~h}$ after placing the seeds on moist filter paper at a temperature of $15^{\circ} \mathrm{C}$ and a

Table 1 The characteristics of control fruits

\begin{tabular}{|c|c|c|c|c|c|c|}
\hline \multirow[t]{3}{*}{ Fruits properties } & \multicolumn{6}{|c|}{ Years of seed reproduction } \\
\hline & \multicolumn{2}{|l|}{2013} & \multicolumn{2}{|l|}{2014} & \multicolumn{2}{|l|}{2015} \\
\hline & $\mathrm{H}$ & L & $\mathrm{H}$ & L & $\mathrm{H}$ & L \\
\hline GA 4th day $[\%] 10^{\circ} \mathrm{C}$ & $18.2 \pm 1.45$ & 0 & $2.2 \pm 0.18$ & $1.8 \pm 0.11$ & $2.5 \pm 0.19$ & $0.5 \pm 0.02$ \\
\hline GA 14 th day $10^{\circ} \mathrm{C}[\%]$ & $99.0 \pm 3.60$ & $96.2 \pm 4.2$ & $96.1 \pm 2.10$ & $93.0 \pm 3.81$ & $98.0 \pm 2.1$ & $92.8 \pm 3.5$ \\
\hline MTG 14th day [days] & $5.6 \pm 0.23$ & $6.9 \pm 0.35$ & $6.2 \pm 0.41$ & $7.1 \pm 0.34$ & $6.2 \pm 0.45$ & $7.4 \pm 0.61$ \\
\hline Electric conductivity of fruits water extracts $\left[\mathrm{mS} \mathrm{cm}^{-2}\right]$ & $1.65 \pm 0.25$ & $2.44 \pm 0.35$ & $1.8 \pm 0.12$ & $3.0 \pm 0.45$ & $1.89 \pm 0.13$ & $2.9 \pm 0.15$ \\
\hline Total porosity [\%] & $48.1 \pm 3.25$ & $43.9 \pm 2.56$ & $47.0 \pm 2.89$ & $44.7 \pm 0.19$ & $46.2 \pm 3.14$ & $44.9 \pm 2.45$ \\
\hline Mesospore diameter [nm] & $5.0 \pm 0.32$ & $1.0 \pm 0.14$ & $2.0 \pm 0.14$ & $1.0 \pm 0.09$ & $2.0 \pm 0.08$ & $1.0 \pm 0.07$ \\
\hline
\end{tabular}

$\mathrm{H}, \mathrm{L}-$ high and low level of seed vigour respectively 
filter paper humidity of $60 \%$ FWC. The material was dried at a temperature of $105^{\circ} \mathrm{C}$ for $6 \mathrm{~h}$, in 4 replicates. The results are expressed as the percentage of water in fresh or dry mass.

\section{Water diffusivity coefficient of the pericarp}

By assuming that seeds have more or less a spherical shape, that water diffusion occurs only through the basal pore and that seeds do not change volume inside their cavity, the Crank diffusion equation can be used [9].

For estimation of water diffusion coefficient, calculations of the seed and fruit radius were necessary. It was assumed, that radius of each fruit to be half seed thickness, plus thickness of pericarp in place of basal pore (place of water entry). Half the length of the seed after extraction from seed cavity was taken as the seed radius. All measurement was carried out using a special micro meter made by the Agrophysics Institute in Lublin.

To determine the water diffusivity coefficient, the seeds were germinated on Petri dishes oat a temperature of $15{ }^{\circ} \mathrm{C}$ and a filter paper humidity of $60 \%$ FWC. After $6,8,24$ and $48 \mathrm{~h}$ of germination, the water content in the pericarp and seeds was determined. The water diffusivity coefficient determines the amount of diffused water per unit area per unit of time. The greater the difference in the water content between the pericarp and the seed at a given time is, the lower the water diffusivity coefficient. The tests were carried out in three replications.

\section{Electrical conductivity of the water extracts}

Three grams of fruit were mixed with deionized water equal to 10 times the volume of the fruit. After $2 \mathrm{~h}$ of stirring, the electric conductivity of the solution was measured using a Conductivity Meter CPC-505 (Elmetron) with EC - 60 electrode (Elmetron). The tests were carried out in three replications.

\section{Assessment of seed germination ability (GA) and germination speed (GS)}

The seeds were germinated in accordance with the general standard of ISTA for sugar beets PN-79/R-65950 in 3 replications of 100 seeds each. Germination was conducted in plastic (ABS) boxes dimensions 220x130x40 $\mathrm{mm}$ under optimum moisture conditions on a filter paper, double pleated strips (2 seeds in a row), grade 3014, nominal thickness $0.22 \mu \mathrm{m}$, nominal weight $113 \mathrm{~g}$ $\mathrm{m}^{-2}$ (Whatman) and humidity of $60 \%$ FWC $(24 \mathrm{ml}$ of water) at temperatures of $10^{\circ} \mathrm{C}$ and $15{ }^{\circ} \mathrm{C}$. Seeds orientation was random. Germination took place in complete darkness in Versatile Environmental Test Chamber MLR-350 (Sanyo).

Germination speed (GS) was estimated in the form of mean time to germinate (MTG) according to the formula $\mathrm{MTG}=\Sigma\left(\mathrm{n}_{\mathrm{i}} \times \mathrm{d}_{\mathrm{i}}\right) / \mathrm{N}$, where $\mathrm{n}_{\mathrm{i}}$ is the number of germinated seeds at day $i, d_{i}$ is the incubation period in days and $\mathrm{N}$ is the total number of germinated seeds.

\section{Statistical analysis}

The obtained data were examined by Standard Error (SE), analysis of variance (ANOVA), and Tukey's test $(p<0.05)$ (STAGRAPHICS Centurion version 18.1.06, 64-bit). Analysis of correlation and regression [35] were used to evaluate the relationship between the pairs of traits. In the tables presented hereafter, different capital and small letters denote the difference at $p<0.05$ in the rows and columns, respectively.

\section{Results}

The assessment of the physical properties of the pericarp is presented in Table 2. The obtained results were characterized by high variability caused by the natural variability of fruit characteristics and difficulties in extracting seeds from fruits.

Seed priming within each level of vigour did not significantly affect helium and apparent density, total pore volume and total porosity. Although no significant differences were found in total porosity depending on seed priming, tendency to increase porosity under the influence of priming could be observed. This is probably why seed priming significantly increased mesopore diameter in both high and low vigour seeds. In porous material such as pericarp, seeds are easiest to absorb water from mesopores, especially when they have a high water potential at the end of germination.

Low seed vigor was significantly associated with an increase in helium and aparent density and a decrease in total pore volume and mezospore diameter. It can be assumed that this could negatively affect the flow of water

Table 2 Physical properties of the pericarp, mean values from 3 years

\begin{tabular}{lllll}
\hline Pericarp properies & $\begin{array}{l}\text { Level } \\
\text { of } \\
\text { vigour }\end{array}$ & \multicolumn{3}{l}{ Seed treatment } \\
\cline { 4 - 6 } & $\mathrm{H}$ & $1.16 \mathrm{Aa}$ & $1.16 \mathrm{Aa}$ & $1.15 \mathrm{Aa}$ \\
\hline Helium density $\left[\mathrm{g} \mathrm{cm}^{-3}\right]$ & $\mathrm{L}$ & $1.31 \mathrm{Ab}$ & $1.30 \mathrm{Ab}$ & $1.28 \mathrm{Ab}$ \\
Apparent density $\left[\mathrm{g} \mathrm{cm}^{-3}\right]$ & $\mathrm{H}$ & $0.62 \mathrm{Aa}$ & $0.60 \mathrm{Aa}$ & $0.60 \mathrm{Aa}$ \\
& $\mathrm{L}$ & $0.70 \mathrm{Ab}$ & $0.70 \mathrm{Ab}$ & $0.70 \mathrm{Ab}$ \\
Total pore volume $\left[\mathrm{cm}^{3} \mathrm{~g}^{-1}\right]$ & $\mathrm{H}$ & $0.77 \mathrm{Ab}$ & $0.79 \mathrm{Ab}$ & $0.80 \mathrm{Ab}$ \\
& $\mathrm{L}$ & $0.65 \mathrm{Aa}$ & $0.63 \mathrm{Aa}$ & $0.64 \mathrm{Aa}$ \\
Total porosity $[\%]$ & $\mathrm{H}$ & $47.1 \mathrm{Ab}$ & $47.8 \mathrm{Ab}$ & $48.3 \mathrm{Ab}$ \\
& $\mathrm{L}$ & $44.5 \mathrm{Aa}$ & $45.0 \mathrm{Aa}$ & $45.3 \mathrm{Aa}$ \\
Mesopore diameter $[\mathrm{nm}]$ & $\mathrm{H}$ & $3 \mathrm{Aa}$ & $5 \mathrm{Bb}$ & $20 \mathrm{Cd}$ \\
& $\mathrm{L}$ & $1 \mathrm{Aa}$ & $3 \mathrm{Ba}$ & $12 \mathrm{Cc}$ \\
\hline
\end{tabular}

H, L - high, low vigour respectively 
through the pericarp and possible wasching out inorganic germination inhibitors.

Effect of different seed treatment methods after 2, 8, 24 and $48 \mathrm{~h}$ since germination test start on water content and water potential of pericarp and seeds are presented in Tables 3 and 4 respectively.

As the germination proces advanced in subsequent time intervals, the pericarp and seeds water content increased gradually (Table 3 ). For the period from 8 to 48 $\mathrm{h}$ significant differences were found in water content of the pericarp control and primed seeds.

After 8,24 and $48 \mathrm{~h}$ the pericarp from the primed seeds was always characterized by a higher water content (1.1 to $5.5 \%)$ than that of the control seeds.

Similarly, as in the case of the pericarp, the water content of the seeds increased as the germination process progressed. Primed seeds in each time interval were characterized by a higher water content ranging from 2.8 to $6.1 \%$. A particularly significant difference in seed water content of 6.1 and $5.4 \%$ occurred between the fruits primed by the QB-1 method and the control fruits after 24 and $48 \mathrm{~h}$ since germination test start.

The water potential of seeds was lower than that in the pericarp in the same time interval (Table 4). After 8 and $24 \mathrm{~h}$ since germination test start, the water potential of the pericarp of primed fruits was always higher than in control fruits.

In the period of 24 to $48 \mathrm{~h}$ of germination, the increase in the water potential was slower than before and amounted to $-0.58 \mathrm{MPa}$ for the pericarp and $-0.80 \mathrm{MPa}$ for the control seeds.

During the germination period from 2 to $48 \mathrm{~h}$, seed priming, especially with the QB-1 method, significantly increased the water potential of the seeds and pericarp. A particularly significant increase in the water potential of the pericarp and seeds occurred between 2 and $8 \mathrm{~h}$ of germination. During this period, the water potential of the control seeds increased by $1.82 \mathrm{MPa}$, while the water

Table 3 Changes in the water content [\%] of the pericarp and seeds after 2, 8, 24 and $48 \mathrm{~h}$ since germination test start at $15^{\circ} \mathrm{C}$ at $60 \%$ FWC. Average results from 3 years of experiments and 2 levels of seed vigour

\begin{tabular}{llllll}
\hline Material & $\begin{array}{l}\text { Seed } \\
\text { treatment }\end{array}$ & \multicolumn{4}{l}{ Water content [\%] } \\
\cline { 3 - 6 } & & \multicolumn{4}{l}{ Time since germination test start [h] } \\
\cline { 3 - 6 } & & 8 & 24 & 48 \\
\hline Pericarp & Control & $23.4 \pm 1.0$ & $25.4 \pm 0.51$ & $36.5 \pm 0.90$ & $43.7 \pm 1.25$ \\
& QB & $20.0 \pm 1.23$ & $30.9 \pm 0.45$ & $38.9 \pm 1.12$ & $48.9 \pm 1.10$ \\
& QB-1 & $22.6 \pm 1.26$ & $29.8 \pm 0.56$ & $38.8 \pm 1.06$ & $44.8 \pm 1.07$ \\
Seeds & Control & $8.2 \pm 0.26$ & $10.8 \pm 0.38$ & $21.9 \pm 1.09$ & $31.6 \pm 0.90$ \\
& QB & $13.2 \pm 0.50$ & $13.8 \pm 0.41$ & $26.2 \pm 0.57$ & $35.8 \pm 0.86$ \\
& QB-1 & $13.0 \pm 0.41$ & $13.6 \pm 0.36$ & $28.0 \pm 0.93$ & $37.0 \pm 1.13$ \\
\hline
\end{tabular}

potential of the seeds primed by the QB-1 method increased by $4.85 \mathrm{MPa}$. Similarly, in the case of the control seed pericarp, the increase in the water potential was $2.29 \mathrm{MPa}$ and that in the QB-1 priming method pericarp was $6.66 \mathrm{MPa}$.

After $24 \mathrm{~h}$ since germination test start the water content of the pericarp from high vigour control fruits was significantly lower $(8.4 \%)$ than that of the pericarp from low vigour seeds (Table 5). Reverse relations occurred in the case of seeds. The water content of seeds from high vigour control fruits was significantly higher (5.4\%) than that of the low vigour seeds.

Differences in the water content of the pericarp were not apparent in the water potential value. The pericarp from low vigour fruits was characterized by a lower water potential compared to the pericarp from seeds with a higher water potential. A lower water content (5.4-8.8\%) of low vigour seeds was also associated with a lower $(-0.59$ and $-0.76 \mathrm{MPa})$ water potential. Considering values for the two levels of seed vigour, priming significantly increased the water content and water potential of the seeds compared to the control.

Moreover, seed priming resulted in a reduction in the differences between the water content of the pericarp with low and high vigour in relation to the control. The differences in the water content of the pericarp from the control fruits were $8.4 \%$ and those in the primed pericarp were 2.0 and $1.4 \%$. Along with the decreases in the differences in water content of the pericarp from the seeds with two levels of vigour, the differences in the seed water content increased. The water content of the control seeds with a higher vigour was $5.4 \%$ higher than the water content of the seeds with low vigour. The seeds with a higher vigour primed by the QB and QB-1 methods were 6.8 and $8.8 \%$ higher than the water content of seeds with low vigour, respectively.

The level of seed vigour had a significant effect on the electrical conductivity of fruit water extracts (Table 6). Seeds with low vigour were characterized by $58 \%$ higher electrical conductivity than seeds with high vigour. For 2 levels of vigour, seed priming caused a significant reduction in the electrical conductivity of aqueous extracts. Therefore, seed priming may directly affect the water content of the seeds and pericarp (Figs. 1 and 2) and the water diffusivity coefficient of the pericarp (Table 7).

Figures 1 and 2 show that as the electric conductivity increases by $1 \mathrm{mS} \mathrm{cm}{ }^{-2}$, the pericarp water content increases by $3.7 \%$ and the seed water content decreases by $7.6 \%$.

The water diffusivity coefficient determines the amount of diffused water per unit area per unit of time. Values of water diffusivity of pericarp for different seed treatments and 2 levels of vigour are shown in Table 7. 
Table 4 Changes in the water potential [MPa] of the pericarp and seeds after 2. 8.24 and $48 \mathrm{~h}$ since germination test start at $15^{\circ} \mathrm{C}$ at 60\% FWC. Average results from 3 years of experiments and 2 levels of seed vigour

\begin{tabular}{|c|c|c|c|c|c|}
\hline \multirow[t]{3}{*}{ Material } & \multirow{3}{*}{$\begin{array}{l}\text { Seed } \\
\text { treatment }\end{array}$} & \multicolumn{4}{|c|}{ Water potential [MPa] } \\
\hline & & \multicolumn{4}{|c|}{ Time since germination test start [h] } \\
\hline & & 2 & 8 & 24 & 48 \\
\hline \multirow[t]{3}{*}{ Pericarp } & Control & $-7.06 \pm 0.51$ & $-3.77 \pm 0.31$ & $-1.65 \pm 0.12$ & $-1.07 \pm 0.21$ \\
\hline & QB & $-6.06 \pm 0.37$ & $-1.94 \pm 0.25$ & $-1.16 \pm 0.22$ & $-1.13 \pm 0.21$ \\
\hline & QB-1 & $-6.59 \pm 0.41$ & $-1.74 \pm 0.28$ & $-1.15 \pm 0.18$ & $-0.93 \pm 0.18$ \\
\hline \multirow[t]{3}{*}{ Seeds } & Control & $-10.51 \pm 0.40$ & $-8.69 \pm 0.35$ & $-3.19 \pm 0.22$ & $-2.39 \pm 0.35$ \\
\hline & QB & $-9.79 \pm 0.22$ & $-7.34 \pm 0.20$ & $-2.83 \pm 0.15$ & $-2.35 \pm 0.23$ \\
\hline & QB-1 & $-10.45 \pm 0.42$ & $-3.79 \pm 0.31$ & $-2.69 \pm 0.23$ & $-2.14 \pm 0.25$ \\
\hline
\end{tabular}

There was a significant difference in the value of the pericarp water diffusivity coefficient depending on the level of seed vigour. The pericarp water diffusivity coefficient of the low vigour seeds, at the same time intervals $(6,24$ and $48 \mathrm{~h})$ and the same fruit treatment was always lower than high vigour seeds.

The value of the pericarp water diffusivity coefficient was relatively constant in the period from 6 to $48 \mathrm{~h}$ of germination. Seed priming caused a significant increase in the average value of the pericarp water diffusivity coefficient in relation to control seeds by 0.01 and 0.03 $\mathrm{cm}^{2} \mathrm{~d}^{-1}$.

Seeds belonging to both groups of vigour had a very similar germination ability of approximately 94-98\%, after 14 days. In contrast, seeds with higher vigour were characterized by faster germination $(0.39-0.99 \mathrm{~d})$ than the seeds with low vigour (Table 8).

On average, for 2 levels of seed vigour, both priming methods significantly accelerated seed germination, the QB method decreased the germination time by 1.29 (high vigour) and 1.17 days (low vigour) and the QB-1 method decreased the germination time by 1.43 (high vigour) and 1.91 days (low vigour).

The QB-1 priming method accelerated the germination of high vigour seeds by only 0.14 days, whereas priming method accelerated the germination of low vigour seeds by as much as 0.74 days in comparison to low vigour seeds.

Relationship between mean germination time (for 2 level of seed vigour and 3 ways of fruits treatment) and pericarp water diffusivity coefficient is presented in Fig. 3.

It is difficult to say to what extent the acceleration of germination was caused by the changes in the biological properties of the seeds or the physicochemical properties of the pericarp. A partial answer to this problem is shown in Fig. 3. The analysis of correlation and regression showed that the average value of the water diffusivity coefficient of the pericarp affects the average MTG value determined at temperatures of 10 and $15^{\circ} \mathrm{C}$. Increasing the average value of the water diffusivity coefficient of the pericarp by $0.01 \mathrm{~cm}^{2} \mathrm{~d}^{-1}$ reduces the mean germination time by 0.2 days.

\section{Discussion}

The data presented in this study indicate that sugar beet seed priming causes not only a relatively well known change in the physiological and biochemical properties of seeds $([5,21,36]$, Herman et al. 2007, [1, 11]) but also a modification in the properties of pericarp, facilitating the flow of water through the pericarp. The obtained results are arranged in a logical sequence of events

Table 5 Comparison of the water content and water potential of the pericarp and seeds depending on the vigour level after $24 \mathrm{~h}$ of germination. Average results from 3 years of experiments

\begin{tabular}{|c|c|c|c|c|c|}
\hline \multirow[t]{2}{*}{ Material } & \multirow{2}{*}{$\begin{array}{l}\text { Fruit } \\
\text { treatment }\end{array}$} & \multicolumn{2}{|c|}{ Water content [\%] } & \multicolumn{2}{|c|}{ Water potential [MPa] } \\
\hline & & High vigour & Low vigour & High vigour & Low vigour \\
\hline \multirow[t]{3}{*}{ Pericarp } & Control & $32.3 \pm 0.52$ & $40.7 \pm 0.53$ & $-1.41 \pm 0.15$ & $-1.89 \pm 0.10$ \\
\hline & QB & $37.9 \pm 0.91$ & $39.9 \pm 0.85$ & $-1.09 \pm 0.12$ & $-1.23 \pm 0.09$ \\
\hline & QB-1 & $38.1 \pm 0.41$ & $39.5 \pm 0.52$ & $-1.05 \pm 0.11$ & $-1.25 \pm 0.08$ \\
\hline \multirow[t]{3}{*}{ Seeds } & Control & $24.6 \pm 0.61$ & $19.2 \pm 0.32$ & $-2.83 \pm 0.15 \mathrm{~A}$ & $-3.55 \pm 0.14$ \\
\hline & QB & $30.1 \pm 0.47$ & $22.3 \pm 0.55$ & $-2.50 \pm 0.12 \mathrm{~A}$ & $-3.09 \pm 0.15$ \\
\hline & QB-1 & $32.4 \pm 0.39$ & $23.6 \pm 0.57$ & $-2.31 \pm 0.13 \mathrm{~A}$ & $-3.07 \pm 0.11$ \\
\hline
\end{tabular}


Table 6 Effect of two levels of seed vigour on the electric conductivity of fruit extracts $\left[\mathrm{mS} \mathrm{cm}^{-2}\right.$ ]. Average results from 3 years of experiments. Fruits were polished and rinsed in water at $20^{\circ} \mathrm{C}$ for $2 \mathrm{~h}$

\begin{tabular}{lll}
\hline Fruit & \multicolumn{2}{l}{ Level of seeds vigour } \\
\cline { 2 - 3 } treatment & High & Low \\
\hline Control & $1.78 \pm 0.05$ & $2.78 \pm 0.08$ \\
QB & $1.64 \pm 0.04$ & $2.63 \pm 0.08$ \\
QB-1 & $1.61 \pm 0.05$ & $2.52 \pm 0.07$ \\
\hline
\end{tabular}

showing the relationship between the water diffusivity of the pericarp and the germination rate of seeds.

Studies have not shown that fruit treatment significantly affected helium and apparent density, total pore volume and total porosity. However, a clear tendency to increase total porosity was observed under the influence of seed priming. This fact probably caused seed priming to increase the diameter of pericarp mesopores from 3 to 20 and from 1 to $2 \mathrm{~nm}$ for high and low vigor seeds respectively.

As a consequence, in the pericarp, the water potential increased particularly strongly after $8 \mathrm{~h}$ of germination. A similar phenomenon occurred in the case of the seeds. After $8 \mathrm{~h}$ of germination, the water potential of the seeds primed by the QB-1 method was $4.9 \mathrm{MPa}$ higher than that in the control seeds. Subsequently, the difference was reduced, but until the germination process was completed, the primed seeds were characterized by a higher water potential than the control seeds. As a result, the seed water potential level of approximately - 1.0 MPa was reached quicker. According to Bradford [4], the radicle (root tip) protruding through and beyond the operculum appears at this level.

A lower level of seed vigour had a higher impact on the water content and water potential of the seeds and

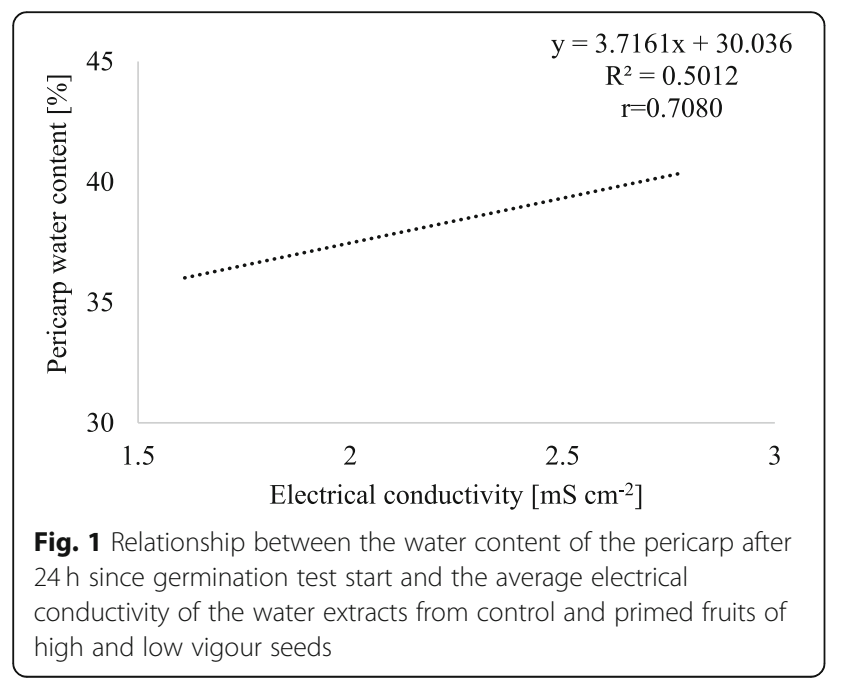

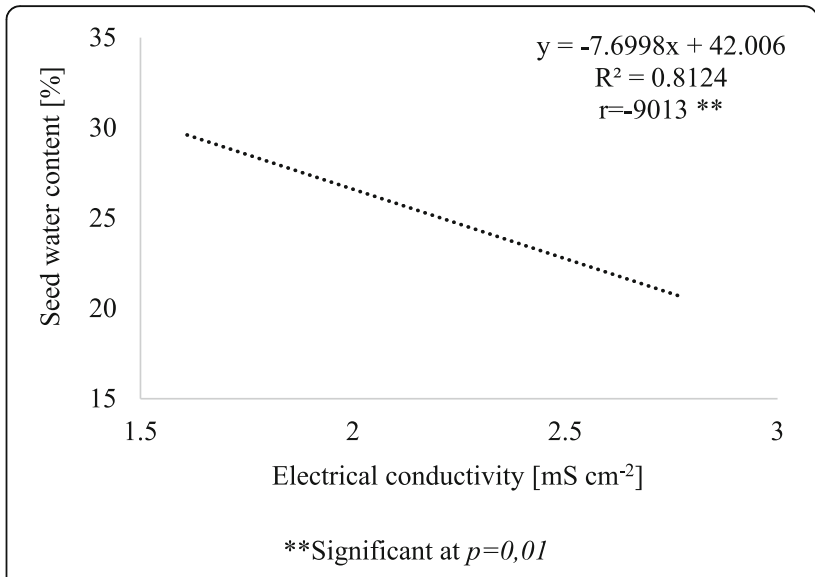

Fig. 2 Relationship between average water content of the seed after $24 \mathrm{~h}$ since germination test start and the electrical conductivity of the water extracts from control and primed fruits of high and low vigour seeds

pericarp than higher vigour. At the same interval time, the low level of vigour increased the pericarp water content and decreased the water content in the seeds, whereas in the case of the water potential, the low vigour of the seeds was associated with the lower water potential value of the pericarp and seeds. Relationship between fruits water absorption and fruit maturity was also shown by Snyder [34] and Salini and Boelt [32] who observed a higher water content in immature fruits. The water content and water potential of the pericarp and seeds were correlated by the electrical conductivity of the aqueous extracts. This value could be a measured by the content of germination inhibitors in forms of inorganic salts. The content of these inhibitors depends

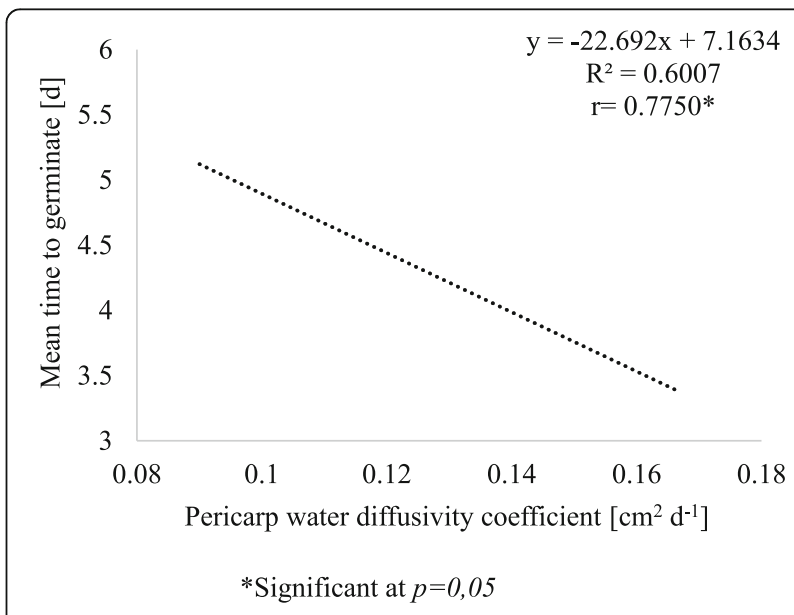

Fig. 3 Relationship between the mean germination time at 10 and $15^{\circ} \mathrm{C}$ after $14 \mathrm{~d}$ and the water diffusivity coefficient of the pericarp after 4,24 and $48 \mathrm{~h}$ of germination. Average results from 3 years of experiments and 2 levels of vigour 
Table 7 Water diffusivity coefficient of the pericarp during seed germination $\left[\mathrm{cm}^{2} \mathrm{~d}^{-1}\right]$ at $15^{\circ} \mathrm{C}$ and $60 \%$ FWC

\begin{tabular}{|c|c|c|c|c|c|c|}
\hline \multirow{3}{*}{$\begin{array}{l}\text { Fruit } \\
\text { treatment }\end{array}$} & \multicolumn{3}{|c|}{ High vigour seeds } & \multicolumn{3}{|c|}{ Low vigour seeds } \\
\hline & \multicolumn{6}{|c|}{ Time since germination test start [h] } \\
\hline & 6 & 24 & 48 & 6 & 24 & 48 \\
\hline Control & $0.14 \pm 0.01$ & $0.14 \pm 0.01$ & $0.14 \pm 0.008$ & $0.08 \pm 0.007$ & $0.09 \pm 0.01$ & $0.10 \pm 0.009$ \\
\hline QB & $0.15 \pm 0.01$ & $0.15 \pm 0.01$ & $0.16 \pm 0.01$ & $0.10 \pm 0.008$ & $0.11 \pm 0.008$ & $0.12 \pm 0.008$ \\
\hline QB-1 & $0.16 \pm 0.009$ & $0.17 \pm 0.01$ & $0.17 \pm 0.01$ & $0.11 b \pm 0.008$ & $0.12 \pm 0.01$ & $0.12 \pm 0.01$ \\
\hline
\end{tabular}

mainly on the environmental conditions during seed maturation and maturity level of seed [26].

Electric conductivity of the seeds leachate can be used as vigour test for seeds of Glycine max, Phaseolus vulgaris, Pisum sativum and Cicer arietinum seeds [17].

Increased water content in the pericarp combined with a reduction in water content in the seeds is evidence of problems with the water flow through the pericarp, which is evidenced by a reduction in the value of the water diffusivity coefficient of the pericarp.

A comparison of average pericarp water diffusivity of the raw fruit $\left(0.00134 \mathrm{~cm}^{2} \mathrm{~d}^{-1}\right)$ from 48 Polish sugar beet lines stock [27] and the diffusivity of pericarp commercial variety Janosik $\left(0.10-0.15 \mathrm{~cm}^{2} \mathrm{~d}^{-1}\right)$ clearly indicates the importance of reproduction seeds in Po Valley (Italy) and proper seed treatment in form of polishing, washing, grading and priming. Similarly, Ignatz et al. [14] confirm that the combined polishing and washing treatment resulting in significant improvements of the germinations performance due to a combined removal of mechanical and inhibitor constraints.

The increase in the water content of the pericarp in fruits with low vigour was accompanied by a decrease in the water potential value in the pericarp. Most likely, the low water potential was caused by the formation of an osmotic solution coming from the dissolving crystals of chemical compounds. Studies by Podlaski [27] have shown that low vigour is usually accompanied by a higher content of chemical compounds in the pericarp, which gradually dissolve, creating an osmotic solution that inhibits water uptake.

In this study, correlations were found between the seed germination rate and the pericarp water diffusivity coefficient. From this statement follows the practical conclusion that the pericarp should be as thin as

Table 8 Mean time to germinate [d] of seeds after 14 days, average results from 3 years of experiments at temperatures 10 and $15^{\circ} \mathrm{C}$

\begin{tabular}{lll}
\hline Fruit & \multicolumn{2}{l}{ Level of seed vigour } \\
\cline { 2 - 3 } treatment & High & Low \\
\hline Control & $4.78 \pm 0.31$ & $5.65 \pm 0.38$ \\
QB & $3.49 \pm 0.28$ & $4.48 \pm 0.28$ \\
QB-1 & $3.35 \pm 0.15$ & $3.74 \pm 0.20$ \\
\hline
\end{tabular}

possible, should not contain crystals of inorganic chemical compounds and organic inhibitors and priming technology should stimulate the water flow through it.

\section{Conclusions}

1. Priming sugar beet seeds by the SMP method significantly increased the mesopore diameter in pericarp.

2. The increase in mesopore diameter and total porosity increases the water content in the pericarp and the water potential value of the seeds.

3. The low vigour of seeds is connected with the higher content of inorganic chemicals in the pericarp, which corresponds to the higher electrical conductivity of water extracts.

4. Seed priming and a higher level of vigour are associated with a higher value of the water diffusivity coefficient of the pericarp.

5. A higher value of the water diffusivity coefficient of the pericarp accelerates seed germination.

Abbreviations

ABA: Abscisic acid; ABS: Acrylonitrile butadiene styrene; AGH: University of science and technology; FWC: Full water capacity; GA: Germination ability;

GS: Germination speed; ISTA: International seed testing association; KHBC: Kutnowska sugar beet breeding company; MTG: Mean time to germinate; QB: Quick Beet; QB-1: Quick Beet-1; SE: Standard error; SEM: Scanning electron microscopy; SMP: Solid matrix priming

\section{Acknowledgements}

Not applicable.

Authors' contributions

CC acquired and interpreted the data regarding the physicochemical properties of the pericarp. SP supervised the experiment and was a major contributor in writing the manuscript. All authors read and approved the final manuscript.

\section{Funding}

This work was supported by the Ministry of Science and Higher Education of the Republic of Poland [grant number PBS1/A8/15/2013]. The funders had no role in study design, data collection and analysis, or preparation of the manuscript. The publication of the article was financed by the Polish National Agency for Academic Exchange as part of the Foreign Promotion Program.

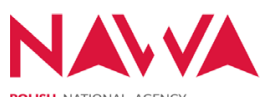

POLISH NATIONAL AGENCY
FOR ACADEMII FXCHANGE

Availability of data and materials

The datasets used and/or analysed during the current study available from the corresponding author on reasonable request. 
Ethics approval and consent to participate

Not applicable.

\section{Consent for publication}

Not applicable.

\section{Competing interests}

The authors declare that they have no competing interests.

Received: 23 September 2019 Accepted: 13 January 2020

Published online: 20 January 2020

\section{References}

1. Abts W. Germination and early root growth of Sugar beet (Beta vulgaris L.) the functioning of ethylene. Leuven: PhD thesis; 2015.

2. Artschwager E. Development of flowers and seed in the sugar beet. J Agric Res. 1927:34:1-25.

3. Blunk S, Malik AH, de Heer M, Ekblad T, Fredlund K, Mooney SJ, Sturrock CJ. Quantification of differences in germination behaviour of pelleted and coated sugar beet seeds using $\mathrm{x}$-ray computed tomography (X-ray $\mathrm{CT}$ ). Biomed Phys Eng Express. 2017;3(4):044001.

4. Bradford KJ (1995) Water relations in seed germination. I: Seed Development and Germination. Kigel J, Galili G. Marcel Dekker Inc., New York, 351-396.

5. Capron I, Corbineau F, Dacher F, Job C. Sugar beet seed priming: effects of priming conditions on germination, solubilisation of 115 globulin and accumulation of LEA proteins. Seed Sci Res. 2000;10(3):243-54.

6. Chachalis D, Smith ML. Seed coat regulation of water uptake during imbibition in soybeans (Glycine max L. Merr.). Seed Sci Technol. 2001;29(2): 401-12.

7. Chomontowski C, Wzorek H, Podlaski S. Impact of sugar beet seed priming on seed quality and performance under diversified environmental conditions of germination, emergence and growth. J Plant Growth Regul. 2019. https://doi.org/10.1007/s00344-019-09973-2.

8. Coumans M, Come D, Gaspar T. Stabilized dormancy in sugar beet fruits. I: seed coats as a physicochemical barrier to oxygen. Bot Gaz. 1976;137:274-8.

9. Crank J. Mathematics of diffusion. Oxford: Brunel University Uxbridge, Clarendon Press; 1975.

10. De Roubaix J, Lazar O. The inhibitory substances contained in sugar beet glomerules. In: Pridham JB, editor. I: Phenolics in Plants in Health and Disease. London: Pergamon Press; 1960. p. 35-42.

11. Girolamo G, Barbanti L. Treatment conditions and biochemical processes influencing seed priming. Ital J Agron. 2012;7(2):178-88.

12. Hadas A (2004) Seedbed preparation: The soil physical environment of germinating seeds. I: Handbook of Seed Physiology. Applications to agriculture Bench-Arnold RL, Sanchez RA (ed.). The Haworth Press, Inc., Binghamton, NY, USA, pp 3-36.

13. Hermann K, Meinhard J, Dobrev P, Linkies A, Pesek B, Hess B, Machácková I, Fischer U, Leubner-Metzger G. 1-Aminocyclopropane-1-carboxylic acid and abscisic acid during the germination of sugar beet (Beta vulgaris L.) a comparative study of fruits and seeds. J Exp Bot. 2007;58(11):3047-60

14. Ignatz M, Hourston JE, Tureckova V, Strnad M, Meinhard J, Fischer U, Steinbrecher T, Leubner-Metzger G. The biochemistry underpinning industrial seed technology and mechanical processing of sugar beet. Planta. 2019:250:1717-29.

15. Inoue K, Yamamoto R. The growth inhibitors in sugar beet balls I. isolation of mono-sodium oxalate as a root growth inhibitor. Proc Crop Sci Soc Jpn. 1974;43(3):430-44.

16. Inoue $\mathrm{K}$, Yamamoto R. The growth inhibitors in sugar beet balls II. Isolation of potassium nitrate as the germination inhibitor and hypocotyl stimulating substance. Proc Crop Sci Soc Jpn. 1975;44(4):465-70.

17. International Seed Testing Association. International Rules for Seed Testing, vol. 1; 2018. p. 15-20.

18. Juntilla O. Germination inhibitors in fruit extracts of red beet (Beta vulgaris cv rubra). J Exp Bot. 1976;27(99):827-36.

19. Lukaszewska E, Sliwinska E. Most organs of sugar beet (Beta vulgaris L.) plants at the vegetative and reproductive stages of development are polysomatic. Plant Reprod. 2007;20:99-107.

20. Manz B, Müller K, Kucera B, Volke F, Leubner-Metzger G. Water uptake and distribution in germinating tobacco seeds investigated in vivo by nuclear magnetic resonance imaging. Plant Physiol. 2005;138:1538-155.
21. McDonald MB. Seed priming. In: Black M, Bewley JD, editors. Seed technology and its biological basis. Sheffield: Sheffield Academic Press; 2000. p. 287-325.

22. Meikle R. Factors affecting the germination and establishment of monogerm sugar beet. Edinburgh: B. Sc thesis: University of Edinburgh, Department of agriculture; 1981. p. 1-81.

23. Pampuch R, Haberko K, Kordek M. Ceramic material science - science on ceramic processes. Warsaw: Wydawnictwo Naukowe PWN; 1992. (in polish).

24. Paparella S, Araújo SS, Rossi G, Wijayasinghe M, Carbonera D. Seed priming: state of the art and new perspectives. Plant Cell Rep. 2015;34(8):1281-93.

25. Perry DA, Harrison JG. Studies on the sensitivity of monogerm sugar beet germination to water. Ann Appl Biol. 1974;77:51-60.

26. Podlaski S, Chrobak Z. Germination ability and germination rate of sugarbeet seeds, in relations to the content of germination inhibitors measured by the conductivity of aqueous extracts of seeds. Seed Sci Technol. 1986;14(3):631-40

27. Podlaski S. Properties of sugar beet fruits affecting seed germination, field emergence and growth of beets. Warsaw: Treatises and Monographs, SGGW-AR Press; 1990. p. 1-107. (in polish).

28. Podlaski S. Properties of sugar beet fruits affecting germination, field emergence and growth of plants. Part III. Factors affecting fruits and seed moisture content. Annu Agric Sci Ser A. 2000;115:31-9 (in polish).

29. Podlaski S, Wzorek H, Chomontowski C. Effects of the physicochemical properties of pellets on the germination of pelleted sugar beet seeds. Int Agrophysics. 2019;33:175-83.

30. Richard G, Raymond P, Corbineau F, Pradet A. Effect of the pericarp on sugar beet (Beta vulgaris L.) seed germination: study of the energy metabolism. Seed Sci Technol. 1989;17:485-98.

31. Santos DSB, Pereira MFA. Restrictions of the tegument to the germination of Beta vulgaris L. seeds. Seed Sci Technol. 1989;17:601-12.

32. Salini Z, Boelt B. Optimization of germination inhibitors elimination from sugar beet (Beta vulgaris L.) seeds of different maturity classes. Agronomy. 2019;9(763):1-11.

33. Scott R, Harper F, Wood D, Jaggard K. Effects of seed size on growth, development and yield of monogerm sugar beet. J Agric Sci. 1974;82(3): 517-31.

34. Snyder FW. Influence of the seed ball on speed of germination of sugar beet seeds. J Am Soc Sugar Beet Technol. 1959;10:513-20.

35. Sokal RR, Rohlf FJ. Biometry. 3rd ed. New York: WH Freeman \& Co.; 1995.

36. Sliwinska E, Jendrzejczak E. Sugar beet seed quality and DNA synthesis in the embryo in relations to hydration-dehydration cycles. Seed Sci Technol. 2002:30(3):597-608.

\section{Publisher's Note}

Springer Nature remains neutral with regard to jurisdictional claims in published maps and institutional affiliations.

Ready to submit your research? Choose BMC and benefit from:

- fast, convenient online submission

- thorough peer review by experienced researchers in your field

- rapid publication on acceptance

- support for research data, including large and complex data types

- gold Open Access which fosters wider collaboration and increased citations

- maximum visibility for your research: over $100 \mathrm{M}$ website views per year

At BMC, research is always in progress.

Learn more biomedcentral.com/submissions 